Institut für Makroökonomie und Konjunkturforschung Macroeconomic Policy Institute

Working Paper

Silke Tober $^{1}$

\title{
Monetary Financing in the Euro Area: A Free Lunch?
}

\begin{abstract}
Two recent proposals for overcoming the euro area crisis make the case for monetary financing of the public sector. Watt (2015) proposes that the ECB finances public investment directly, Pâris and Wyplosz (2014) contend that public debt may be effectively restructured by burying parts of it in the balance sheet of the Eurosystem. Both proposals place the ECB at the center of matters generally considered to be fiscal in order to circumvent existing fiscal and political constraints. This paper argues that neither monetary debt retirement nor monetary financing of EU investment are a free lunch. Both proposals fudge the line between monetary and fiscal policy thereby ignoring valid reasons for separating these two macroeconomic policy areas. All monetary policy measures impact on government finances; whether monetary policy actions cross the fiscal policy line, however, depends primarily on the underlying motivation of the action. In the case of the two proposals the motivation is unambiguously fiscal.
\end{abstract}

${ }^{1}$ Macroeconomic Policy Institute (IMK) in the Hans-Böckler Foundation, silke-tober@boeckler.de. 


\title{
Monetary Financing in the Euro Area: A Free Lunch?
}

\author{
Silke Tober ${ }^{1}$ May 2015
}

\begin{abstract}
Two recent proposals for overcoming the euro area crisis make the case for monetary financing of the public sector. Watt (2015) proposes that the ECB finances public investment directly, Pâris and Wyplosz (2014) contend that public debt may be effectively restructured by burying parts of it in the balance sheet of the Eurosystem. Both proposals place the ECB at the center of matters generally considered to be fiscal in order to circumvent existing fiscal and political constraints. This paper argues that neither monetary debt retirement nor monetary financing of EU investment are a free lunch. Both proposals fudge the line between monetary and fiscal policy thereby ignoring valid reasons for separating these two macroeconomic policy areas. All monetary policy measures impact on government finances; whether monetary policy actions cross the fiscal policy line, however, depends primarily on the underlying motivation of the action. In the case of the two proposals the motivation is unambiguously fiscal.
\end{abstract}

\section{Introduction}

The euro area is in its eighth year of economic crisis. In the aftermath of the international financial crisis and the Great Recession 2007-2009, the euro area slid into the euro area crisis - as much due to policy mistakes and institutional inadequacies as to imbalances that had built up during the first nine years of its existence. Between 2008 and 2014 real GDP declined on average by $0.1 \%$ per year and, in 2014 , was $1 \%$ lower than in 2007 . Unemployment in early 2015 stood at $11.3 \%$ with youth unemployment at $22.9 \%$ in the euro area as a whole and exceeding 50\% in Spain and Greece. During the past seven years, investment in the euro area has declined by an average annual rate of $2.7 \%$ and the level of investment in 2014 was $19 \%$ lower than in $2007 .^{2}$

Against this background, the most pressing issue in the euro area is raising production to the level of potential output, i.e. to close the output gap. This requires demand-side policies. As ECB president Draghi (2014) recently put it, “(d)emand side policies are not only justified by the significant cyclical component in unemployment. They are also relevant because, given prevailing uncertainty, they help insure against the risk that a weak economy is contributing to hysteresis effects. “3 Closing the output gap is necessary to alleviate the hardship of unemployment, increase the standard of living, reduce economic and political instability and lower the debt ratio of both the private and the public sector.

\footnotetext{
${ }^{1}$ Macroeconomic Policy Institute (IMK), Duesseldorf, Silke-Tober@boeckler.de. Helpful comments from Kai Daniel Schmid and Fabian Lindner are gratefully acknowledged.

${ }^{2}$ Data is found in Eurostat Ameco database updated 5 May 2015, unless noted otherwise.

${ }^{3}$ Problems of measuring the output gap and hysteresis are discussed in Gechert/Rietzler/Tober (2015) and Logeay/Tober (2006).
} 
Raising aggregate demand is all the more important as core inflation and inflation expectations have declined to low levels with direct negative effects on the economy and on the role of the ECB's inflation target as an economic stability anchor (Chart 1). Despite some blunders

\section{Chart 1:}

Inflation and inflation expectations in the euro area ${ }^{*}$

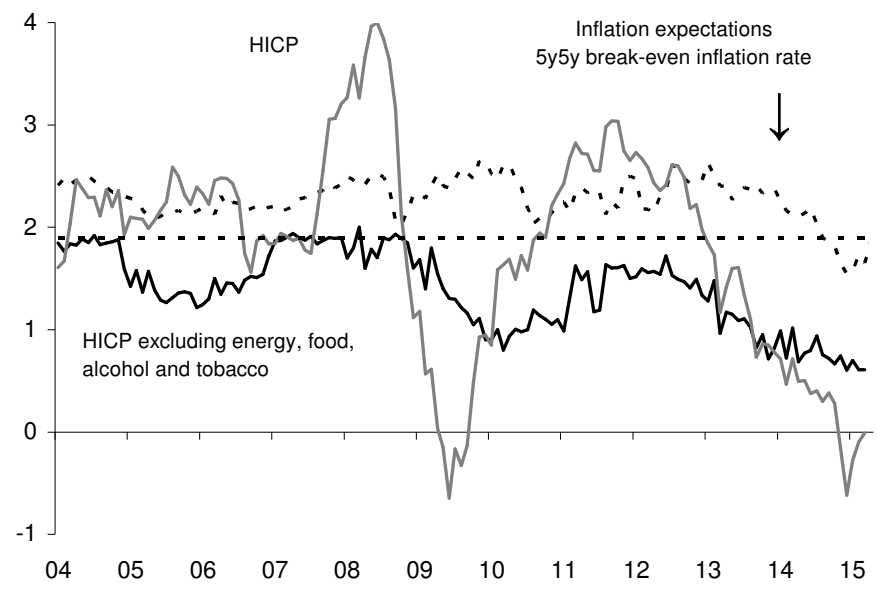

*Harmonised Consumer Price Index (HICP), percentage change m/m-12; 5-year

forward break-even inflation rate 5 years ahead; ECB inflation target $=1.9 \%$

Sources: European Central Bank; Eurostat. and sluggishness, the ECB has been very active in stabilizing demand: by decreasing interest rates and increasing liquidity, intervening in bond markets and bolstering confidence. In contrast, fiscal policy, spooked by financial markets, tended to depress demand through austerity. As a result, the euro area economy by and large stagnated and, until recently, public debt ratios continued to rise as GDP declined and public expenditure rose in response to the faltering economy.

With interest rates near zero, monetary policy has few options left.

Furthermore, monetary policy only indirectly affects consumption and investment. In the current situation, it would be more effective to increase aggregate demand directly. Fiscal multipliers can be expected to be in a higher range, especially in the countries hardest hit by the crisis (Gechert et al. 2015a). Because of the self-imposed restrictions on euro-area fiscal policies and concerns over increasing fiscal deficits, some economists are calling for expanding the role of monetary policy to areas hitherto defined as fiscal, such as retiring public debt (Pâris/Wyplosz 2014) and directly financing public investment (Watt 2015, iAGS 2014).

This policy brief argues that neither monetary debt retirement nor monetary financing of EU investment are a free lunch. They also come at the cost of fudging the line between monetary and fiscal policy. All monetary policy measures inevitably impact on government finances; whether monetary policy actions cross the line depends on the underlying motivation of the action.

\section{Monetary Financing - what it is and what it is not}

History is littered with examples of governments using the central bank to finance public expenditure when they were unable or unwilling to raise the money on capital markets or by increasing taxes. More often than not, the result was spiraling inflation as "too much money chased to few goods". In recent history, Germany twice experienced a complete erosion of its money system: In 1923, the direct effect of monetary financing was dwarfed by a subsequent confidence loss that led to a sharp increase in the velocity of money; hyperinflation 
completely wiped out savings and a new currency was introduced at a ratio of 1 trillion to 1 . During and after WWII price controls and rationing prevented open inflation but instead caused a shortage of goods and thriving black market activity. To restore monetary order a monetary reform was carried out in 1948 that cancelled out $90 \%$ of credits and savings.

The prohibition of central bank financing of public entities was written into central bank statutes to prevent similar abuses of the central banks' ability to print money. Article 123 of the Lisbon Treaty states that the Eurosystem may not grant public entities any type of credit facility or "purchase directly from them by the European Central Bank or national central banks of debt instruments." In addition, the ECB "shall be independent in the exercise of its powers and in the management of its finances" and is given "the primary objective ... to maintain price stability" (Art. 282, Lisbon Treaty).

The prohibition of monetary financing is neither necessary nor sufficient to ensure price stability. Its purpose is to protect the central bank's independence and ability to maintain price stability which could be undermined if governments had direct access to central bank financing. Given the complexity of the issue, the spirit, not the letter of the law is paramount. Secondary market purchases carried out with the objective of circumventing the prohibition of monetary financing would be a violation. ${ }^{5}$ Conversely, purchasing sovereign bonds selectively to eliminate market distortions that reduce the efficacy of monetary policy transmission - as in the ECB's OMT $-{ }^{6}$ do not constitute monetary financing (Tober 2014, Villalón 2015). ${ }^{7}$ It is also conceivable that specific primary market purchases constitute monetary policy rather than monetary financing; in general, such a violation of the letter of the law is not necessary from a monetary policy point of view, however. In a nutshell: Whether a given monetary policy operation is monetary financing of governments in the sense

\footnotetext{
${ }^{4}$ Art. 123, Lisbon Treaty: „1. Overdraft facilities or any other type of credit facility with the European Central Bank or with the central banks of the Member States (hereinafter referred to as 'national central banks') in favour of Union institutions, bodies, offices or agencies, central governments, regional, local or other public authorities, other bodies governed by public law, or public undertakings of Member States shall be prohibited, as shall the purchase directly from them by the European Central Bank or national central banks of debt instruments."

${ }^{5}$ This view is also held by Advocate General of the European Court of Justice Villalón (2015: 227): "In other words, the Treaty does not prohibit operations on the secondary market but it does require that, when the ECB intervenes on that market, it does so with sufficient safeguards to ensure that its intervention does not fall foul of the prohibition of monetary financing."

${ }^{6}$ Outright Monetary Transactions (OMT) refer to a decision of the ECB in September 2012 to under certain circumstances engage in secondary market government security purchases to safeguard "an appropriate monetary policy transmission and the singleness of the monetary policy". Not activated so far, OMT would extend only to securities of euro area countries that apply for a EFSF/ESM program and be limited to the shorter part of the yield curve (1-3 years), but not in size. (http://www.ecb.europa.eu/press/pr/date/2012/html/pr120906_1.en.html)

${ }^{7}$ In response to the German Federal Constitutional Court that viewed selective asset purchases as beyond the scope of monetary policy and as monetary financing, the Advocate General of the European Court of Justice noted: "Therefore, selectivity is merely the logical consequence of a programme seeking to remedy a situation in which the monetary policy transmission channels are blocked in various Member States. The fact that there may be changes in the market or that the government bonds of other States may be placed at a disadvantage does not affect the classification of the OMT programme as a monetary policy measure, since it is only by targeting the programme at the bonds of the States concerned that the efficacy of the programme can be ensured." (Villalón 2015: 227)
} 
of Article 123 Lisbon Treaty depends not on the effect the operation has on the financing costs of governments but rather on its underlying objective.

\section{Direct central bank financing}

Two recent proposals for overcoming the euro crisis make the case for monetary financing of the public sector. Whereas Watt (2015) proposes that the ECB directly finances investment, Pâris and Wyplosz (2014) argue public debt may be effectively restructured by burying parts of it in the balance sheet of the Eurosystem, i.e. of the ECB and the euro-area national central banks. Both proposals involve placing the ECB at the center of matters generally considered to be fiscal in order to circumvent existing fiscal and political restrictions. Watt (2015), furthermore, suggests that monetary financing of investment in the current economic environment implies that there is no cost of financing. ${ }^{8}$

\section{Monetary Financing of EU investment: A Free Lunch?}

In Watt's proposal, the European Investment Bank (EIB) finances public investment projects in the euro area with newly issued EIB bonds which the ECB promises to purchase. ${ }^{9}$ Because of this ex ante guarantee, ${ }^{10}$ interest rates are expected to remain low and the EIB is expected to maintain its Triple-A rating despite increasing its bond issue markedly - by $€ 250$ billion in the first year and $€ 750$ billion in all. Currently the volume of EIB debt securities is $€ 406$ billion, the volume of EIB loans $€ 428$ billion implying an increase of $185 \%$ and $175 \%$, respectively (EIB 2014: 5, 25, 105). The proposal endeavors to show that such an increase in credit-financed investment is possible without an increase in debt for a period of ten years and, in one version, at no cost at all.

Watt's objective is to raise public investment as a means of bolstering growth. Given economic slack in the euro area this is a reasonable suggestion, especially as monetary policy rates have reached their lower bound. The problem Watt attempts to tackle is the funding of these investments given institutional fiscal constraints and the reluctance of even those countries with obvious fiscal space to increase their debt. The issue of financing is currently all the more difficult as the positive effects of increased investment would be largest in the countries worst hit by the crisis but least able to generate the necessary financial means. Given these difficulties, Watt puts forth a funding method professed to generate neither new debt nor interest payments. The only worry of policy makers in this proposal is to spend the money in accordance with the wishes of the people they represent.

\footnotetext{
8 "..for a limited time public investment can be financed costlessly through the issue of base money. Indeed, such investment is not just a free lunch, it is a meal that diners are being paid to eat." (Watt 2015, p. 20).

${ }^{9}$ The proposal's key feature of the ECB-backed EIB bonds is also found in Varoufakis et al. (2013). These authors, however, neither claim that such investments entail no cost nor call for an ex-ante ECB guarantee.

${ }^{10}$ A guaranteed purchase "on the secondary market" Watt $(2015$, p. 2$)$, in my opinion, differs from a purchase on primary markets in name only.
} 
The main flaw in the argument is that, contrary to Watt's assertion, debt does not disappear when shifted to the central bank. Watt is simply wrong when he argues that the position that "debt cannot disappear" "confuses a central bank with a commercial bank" (Watt 2015, p. 19). The fact that a central bank, unlike commercial banks, can absorb these losses and operate effectively even with negative capital in no way implies that the losses are not "real". ${ }^{11}$

\section{Chart 2: Consolidated financial statement of the Eurosystem on 1 May 2015}

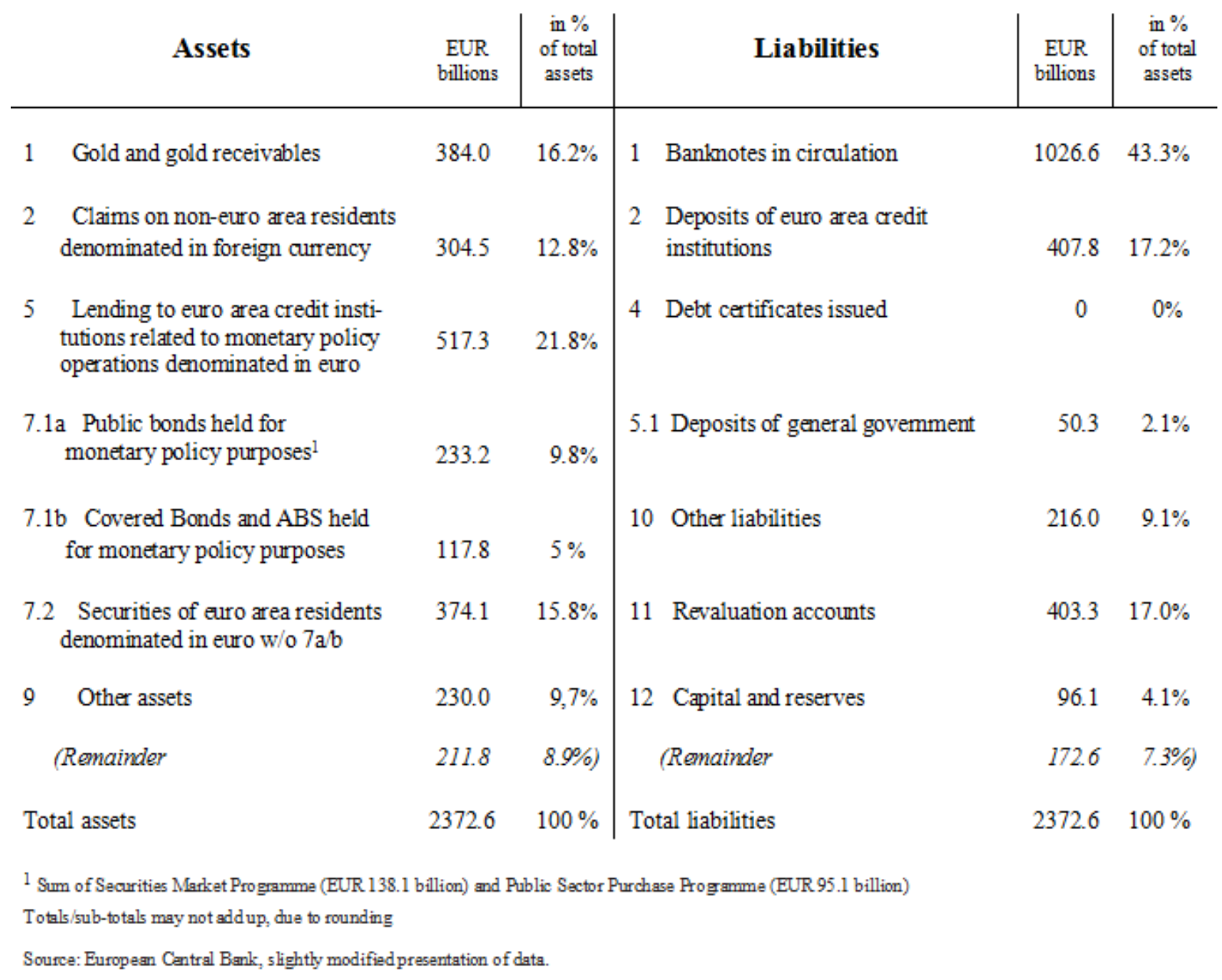

Bonds purchased by the Eurosystem lengthen its balance sheet (Chart 2): Position 7 on the asset side increases at the same time as deposits (position 2) or banknotes in circulation (position 1) on the liabilities side. If these assets become worthless - for example as a result of being transformed into perpetual zero-interest bonds -, capital and reserves (position 12) absorb this loss. ${ }^{12}$ For

\footnotetext{
${ }^{11}$ Watt's line of argument is echoed in iAGS (2014, p. 129): "A more radical proposal - although in fact it is much less so than it might appear - would be to extend the central bank holding period to "for ever", in essence removing the need for countries to repay the debt to the central bank. ... The debt might just as well be extinguished. There is no real "loss" to the central bank in doing so."

${ }^{12}$ The Eurosystem's revaluation accounts cannot be used to absorb such losses. Their purpose is to reflect unrealised gains resulting from an increase in the market value of financial assets and provide a buffer in case of a decrease in the market value. Furthermore, unrealised losses in any one security or currency or in gold may not be netted against unrealized gains in other securities or currencies or gold (Vergote/Studener 2010, p. 26).
} 
example, if EIB bonds worth $€ 750$ billion become worthless, the position capital and reserves declines from the current $€ 96$ billion to $-€ 654$ billion.

The ECB's current asset purchase program does not change this link in the slightest. The ECB has decided to purchase government bonds, other public bonds and covered bonds in the amount of $€ 1$ trillion between March 2015 and September 2016 (ECB 2015). This only means that the ECB does in fact wish to increase the liquidity available to banks. If this were not the case, but the ECB were nonetheless required to purchase EIB bonds, it would have to reabsorb the liquidity it created when purchasing the bonds by issuing debt certificates in the same amount (position 4). Irrespective of whether deposits, banknotes or issued debt certificates on the liability side are the counterpart of the EIB bonds on the asset side, if the EIB bonds become worthless, capital and reserves are reduced by the same amount.

The no-cost argument carries no more weight when applied to the suspension of interest payments on newly issued EIB bonds (for a period of 10 years). Firstly, the fiscal position remains the same, whether investment is financed regularly by issuing government bonds or irregularly through EIBECB monetary financing. In the former case, governments pay interest, in the latter, the central bank profits transferred to the governments are lower by the amount of interest not earned on EIB bonds. Expenditure is higher in the first case, receipts are lower in the second, but the fiscal balance is unaffected. ${ }^{13}$

The only benefit of monetary financing - always the assuming that the ECB does not throw its inflation target overboard - would be to construct the new debt in such a way that would make it "disappear" or at least not be counted towards the debt criterion of the EU fiscal compact. As discussed above, debt does not disappear by shifting it to the central bank. The question that remains is whether one can hide the new debt from Eurostat by issuing EIB bonds which the ECB subsequently buys. This appears highly unlikely. The EIB would be disbursing funds - assets on its balance sheet balanced by bonds issued on the liabilities' side - which do not appear as liabilities on any financial account. Someone is sure to notice, even if they missed the process of getting the proposal approved by various political bodies and the consent of the ECB.

It follows that Watt's trouser pockets analogy misses the point not on one but on two counts: Firstly, financing investment in the euro area involves the creation of new debt whether held by government or the Eurosystem; the trouser analogy would apply, at best, in the case of shifting existing debt. ${ }^{14}$ Secondly, Watt misses the crucial point that fiscal authorities and monetary authorities have different objectives: A central bank that is given the job of "extinguishing" debt or financing public investment is likely to incur a conflict of interest. This potential

\footnotetext{
${ }^{13}$ If financing costs of governments and central banks differ the fiscal balance may be affected but that is not relevant to the present argument. It is also irrelevant whether the balance sheet lengthens by the amount of EIB bonds or banks instead shun the extra liquidity and reduce their liabilities to the Eurosystem.

14 "The sums merely change from one pocket to another of the government's "trousers" (Watt 2015, p. 24; iAGS 2014 , p. 128). In the euro area, the trouser analogy is even less fitting because there is no fiscal union and the proposal calls - in all but one version, which is qualified as ineffective - for extensive redistribution between member states.
} 
conflict of interest is moreover a logical consequence of Watt's proposal because its raison d'être is the lack of political will to finance and redistribute through regular channels.

Wren-Lewis (2013) rightly commented on the recent proliferation in helicopter money proposals as follows: "The macroeconomist in me wants to complain: as I have said in the past, helicopter money is either a plea for fiscal expansion - which is good, but why not call it that - or a policy for above target future inflation, which may also be good but why not call it that too?"

Watt' proposal (2015) is, firstly, a plea for fiscal expansion that, secondly, purports to show that it can be done at no cost and without increasing the public debt level and, thirdly, calls in question the inflation target of the ECB: The monetary financing is supposed to continue even when inflation overshoots the ECB target of $1.9 \%$ : "For instance central bank purchases could be wound down to zero over a six month period after the core inflation rate in the euro area has exceeded $2.5 \%$ for three consecutive months" (Watt 2015, p. 24). In the earlier version of the paper (iAGS 2014), the Eurosystem is to continue the purchases of EIB bonds until the entire $€ 750$ billion have been used for public investment, which "would be noninflationary as private-sector liquidity would be absorbed (iAGS 2014, p. 128). Given that lending to euro-area credit institutions currently stands at $€ 517$ billion, this would amount to a complete redesign of monetary policy operations. There may be good reasons for such a change, but financing current public expenditure is not among them.

\section{Burying public debt in the Eurosystem's balance sheet}

Unlike Watt (2015), Pâris and Wyplosz $(2013,2014)$ do not claim that debt disappears once shifted to the Eurosystem; they merely hold that such a transfer would be a politically acceptable and effective way of restructuring. The authors propose that the ECB buy a certain portion of euro-area government bonds and transform these into interest-free perpetual bonds to remain on its balance sheet. The original 2013 proposal was to add a quarter of the debt of Greece, Ireland, Portugal, Italy, Spain and France to the ECB’s balance sheet ( $€ 1200$ billion) to be paid for in the long run by all countries in the shape of reduced profits of the Eurosystem. ${ }^{15}$ The current plan (PADRE) ${ }^{16}$ abandons the idea of large scale redistribution within the euro area and instead recommends halving euro-area sovereign debt by transferring it to the Euosystem's balance sheet. According to the authors, "the financing is simple" (Pâris/Wyplosz 2014): Each country's debt is reduced according to its ECB capital share and each country pays for its own debt reduction because ECB seignorage is paid out in accordance to the capital share and these profits will be lower "over the indefinite future." Future earnings are thus securitized and shelved at the ECB.

\footnotetext{
15 "Suppose all the other Eurozone countries forgive a quarter of the debts of Greece, Ireland, Portugal, Italy, Spain and France. This represents a write-down for 'forgiven' countries' debt that amounts to about $€ 1200$ billion. That is about 30\% of the 'forgiving' countries' GDPs“" (Pâris/Wyplosz 2013).

${ }^{16}$ PADRE stands for Politically Acceptable Debt Restructuring in the Eurozone (Pâris/Wyplosz 2014).
} 
For the sake of brevity I focus on only two points: First, the claim that such a scheme does not involve the monetization of debt and, second, that the drastic increase in the balance sheet of the Eurosystem is irrelevant for effectiveness of monetary policy.

In the first step, the scheme necessarily involves a monetization of public debt because the Eurosystem can only buy the existing government debt with the means of payment it creates, i.e. deposits of banks and currency in circulation. After all, this ability of the Eurosystem to create the means of payment is the key reason for involving the Eurosystem in the first place. Pâris and Wyplosz (2014b) argue that the plan does not involve monetization because the Eurosystem would issue debt certificates (liability 4 in Table 2) to absorb the newly created liquidity. It may be semantics to argue that sterilized monetization is nonetheless monetization, the more important point, however, is that the PADRE plan unquestionably involves monetary financing as outlined above.

Table 2 shows the reduction in the debt ratios of individual countries according to the PADRE-Plan and the effect on the Eurosystem's balance sheet. Whereas the initial proposal in 2013 was more manageable in size ( $€ 1200$ billion) but involved large-scale redistribution within the euro area not in line with the prevailing objectives of policy makers, the current proposal entails a transfer of such magnitude that it is likely to impair the effectiveness of monetary policy. A central bank's credibility hinges on its ability to ensure the stable value of its currency. In the event of a loss of confidence in financial markets, the central bank has to be ready to intervene on foreign exchange markets to prevent strong depreciation, for

Table 2: Effect of the PADRE-Plan on debt ratios in the Euro Area and on the Eurosystem*

\begin{tabular}{l|rrr}
\hline \multicolumn{2}{c}{$\begin{array}{c}\text { Debt reduction in } \\
\text { \% of GDP }\end{array}$} & $\begin{array}{c}\text { Debt reduction } \\
\text { in } € \text { billions }\end{array}$ & $\begin{array}{c}\text { New debt ratio } \\
\text { in \% }\end{array}$ \\
\hline Euro Area & 47.1 & 4766.6 & 47.1 \\
Germany & 42.0 & 1218.7 & 32.8 \\
Greece & 76.9 & 137.7 & 100.2 \\
Italy & 51.6 & 833.6 & 80.5 \\
Spain & 56.6 & 598.7 & 41.1 \\
Memo: Balance sheet increase & Ebillion & in \% \\
\multicolumn{2}{l}{ Eurosy stem } & \multicolumn{2}{|c}{201} \\
\hline
\end{tabular}

* 50\% reduction in euro-area government debt as in the Padre-Plan (Pâris/Wyplosz 2014) using data for 2014 as in Eurostat's Ameco database (May 2015). Consolidated balance sheet of the Eurosystem as on 1 May 2015 .

Sou rces: Eu rostat; ECB; author's calculations. example. A financially strong central bank can easily obtain a credit line from other central banks. However, if the ECB is already saddled with worthless assets amounting to $47 \%$ of the euro area GDP and $2 / 3$ of its total assets, the credibility of announcing that it will defend a given exchange rate is not likely to be high. The same goes for interventions in domestic markets. Our monetary system is based on fiat money not backed by gold or

other assets. However, the acceptance of the euro as a reliable store of value cannot be decreed. It rests in the credibility of the central bank and its ability to regain that credibility should it falter.

In addition to the issues revolving around monetization and central bank credibility, a third questionable feature of the plan involves the prospect of eventually "retiring" the debt using 
future seignorage. The Eurosystem is unlikely to generate any profits for a long time if the PADRE plan is implemented. Two-thirds of its assets will not earn any interest whereas interest is due on its liabilities save for banknotes. Banknotes would account for less than one sixth of total liabilities, being dwarfed by the debt certificates issued to absorb the liquidity generated by government bond purchases worth $€ 4.8$ trillion. In the absence of other changes to the refinancing operations, the Eurosystem is therefore likely to operate not only with negative capital but also with operational losses. Pâris and Wyplosz (2014b) concede that the Eurosystem would sustain substantial operational losses for a period of more than 5 decades.

\section{Conclusion}

Monetary financing of public investment is not a free lunch as contended by Watt (2015). Although EIB-ECB financing would mean that governments do not pay interest on the funds used for public investment, the Eurosystem would not earn interest on the corresponding assets thus generating less profit than in the case of standard quantitative easing. Provided the ECB pursues its inflation target, the impact on the fiscal budget is the same whether public investment is financed regularly or by the central bank. ${ }^{17}$

Concerning the impact on public debt ratios, there is the slim chance that the factual increase in public debt can be hidden from the watchful eye of Eurostat and the EU Commission by using the EIB-ECB construction. This, however, would imply that the euro-area governments agree to circumvent the rules they themselves laid down rather than using the room for maneuver these rules entail (EU Commission 2015). Monetary financing of public investment bears not only the same costs as regular financing but the further cost of fudging the line between monetary and fiscal policy and, in addition, weakening the effectiveness of monetary policy by saddling the Eurosystem with $€ 750$ billion in non-interest-bearing assets.

The balance-sheet effect is even greater in the case of the PADRE plan (Pâris/Wyplosz 2014). This proposal essentially amounts to a debt redemption fund ${ }^{18}$ with the key difference that the "excessive" debt is held by the central banks and future seignorage is earmarked for debt servicing.

In Watt (2015) and in Pâris/Wyplosz (2014) the Eurosystem is used to hide the implications of a recommended policy action in the hope of making it politically more acceptable. For a whole slew of reasons - not least stability, transparency and democratic accountability central banks and policy makers in general should say what they do and do what they say (Artis et al. 1998: 1824).

\footnotetext{
${ }^{17}$ See footnote 13 .

${ }^{18}$ The idea of a debt redemption fund through which euro-area countries jointly and severally guarantee but individually service legacy government debt above $60 \%$ of GDP was developed by the German Council of Economic Experts (2011) and Parello/Visco (2012); see also Tober (2014b) and Tumpel-Gugerell et al. (2014).
} 
Chart 3: Ten-year sovereign bond yields of selected euro area countries, in \%, daily

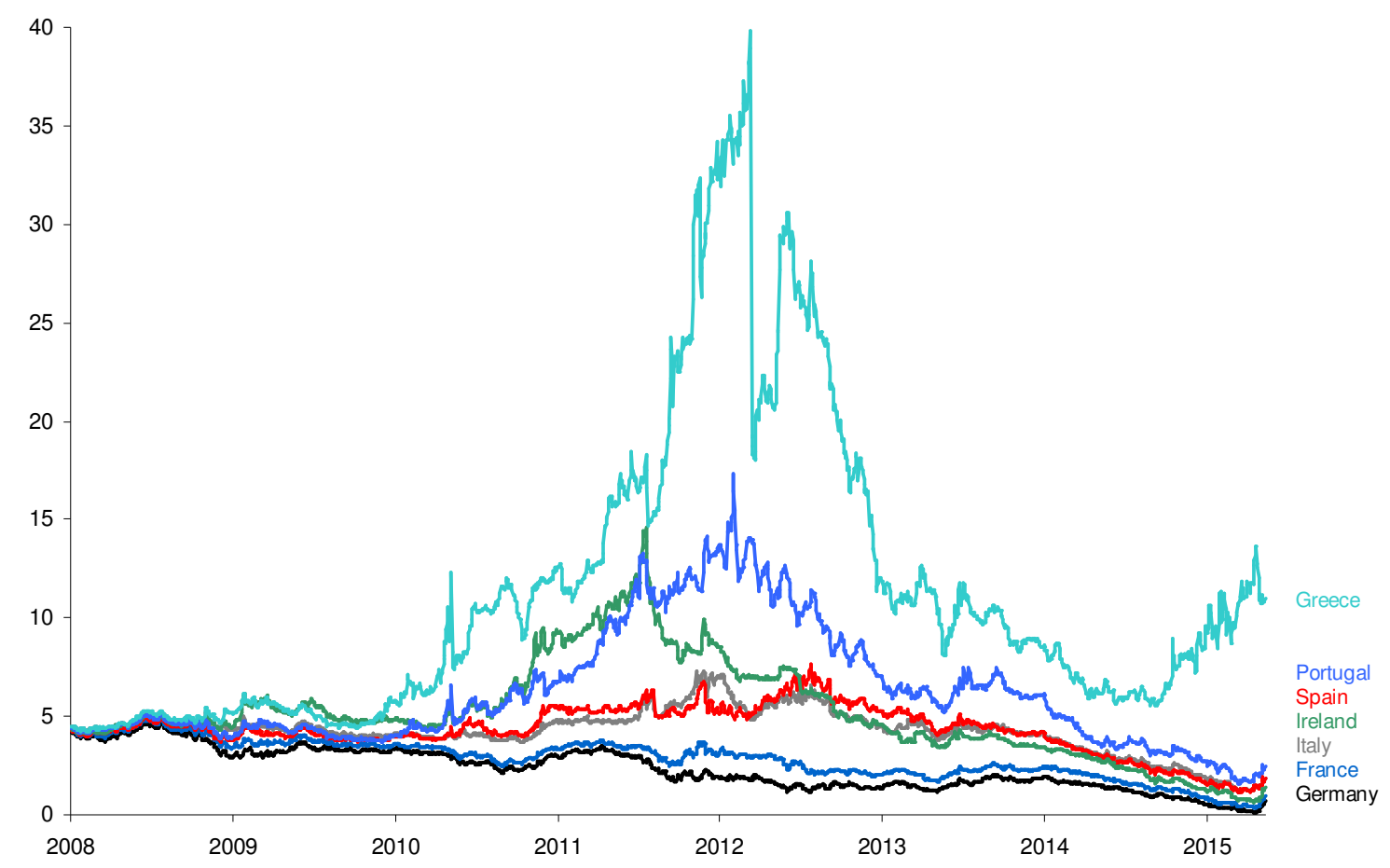

Source: Reuters EcoWin (EcoWin Financial).

The euro area is currently faced with the problem of large output gaps, high uncertainty, low growth and high debt ratios. In all euro area countries, with the possible exception of Greece, the key challenge is not to restructure debt but to close the output gap and steer the countries onto a stable growth path. As GDP increases, debt ratios decline. Economic growth is the main mechanism through which public debt ratios will decline - whether hidden in the Eurosystem's balance sheet or not.

Fiscal policy is likely to be more effective than monetary policy in the current low-interest environment. However, there is absolutely no need to violate Art. 123 of the EU treaty or the budgetary authority of the national parliaments in order to increase public investment. Given the very low level of government bond yields (Chart 3), it is primarily the interpretation of the fiscal rules that prevent regular financing of public investment. ${ }^{19}$ Since the euro area is obviously in an unexpected adverse economic situation - GDP forecast are repeatedly revised down, inflation expectations are declining - fiscal deficits could be increased even in those countries that currently are said not to have fiscal space. To achieve financing at a euro area level, eurobonds or eurobills could be issued (Bofinger 2013, Graham 2013; Horn et al. 2015). These would then constitute high-quality bonds the ECB can use for QE. But unlike the EIB bonds proposed by Watt (2015) they would not be high quality bonds because the

\footnotetext{
${ }^{19}$ Is a constellation conceivable in which aggregate demand needs to be stimulated rapidly and the central bank is the only macroeconomic actor able to act? Yes, this is a possibility, especially if policy action has been delayed. Helicopter money may then be the most effective way of preventing a slide into deflation. But it is important to be upfront about the fact that an increase in debt is an increase in debt whether held by the central bank or other public entities.
} 
ECB uses them for QE. And it would be clear to all what the costs are and who bears them. "Future generations will not understand why [euro-area] governments did not invest in productive assets that improve their welfare, while these governments could do so at historically low financing costs" (De Grauwe 2014).

In order to fortify the euro area against financial shocks in the future and reduce the current level of uncertainty, the ECB needs to be able to act as an effective backstop for public debt (De Grauwe 2013). ${ }^{20}$ Saddling the ECB with non-interest bearing debt would not only weaken the central bank in general but also its ability to perform this role. ${ }^{21}$

\section{References}

Artis, M.; Mizen, P.; Kontomelis; Z. (1998): Inflation Targeting: What Can the ECB Learn From the Recent Experience of the Bank of England? The Economic Journal, 108, November 1998, S. 1824.

Bishop, G. (2013): Bolstering the Still-Fragile Euro: A Plan for a Temporary Eurobill Fund. February.

Bofinger, P. (2013): With Basket-Eurobonds the ECB could act like the Fed. Progressive Economy, 2013, p. $55-59$.

De Grauwe, P. (2014): Stop Structural Reforms And Start Public Investment In Europe. Social Europe Journal, 17 September 2014.

De Grauwe, P. (2013): Design Failures in the Eurozone - can they be fixed? European Economy, Economic Papers 491, Brussels, April 2013.

Draghi, M. (2014): Unemployment in the euro area. Speech by Mario Draghi, President of the ECB. Annual central bank symposium in Jackson Hole, 22 August.

ECB (2015): ECB announces expanded asset purchase programme. Press release, Frankfurt, 22 January 2015.

EIB (2014): Financial Report 2013. European Investment Bank, Luxembourg.

EU Commission (2015): Making the best use of the flexibility within the existing rules of the Stability and Growth Pact. COM (2015) 12, Strasbourg,13.01.2015.

Gechert, S.; Hughes Hallett, A,: Rannenberg, A. (2015a): Fiscal multipliers in downturns and the effects of Eurozone consolidation. CEPR Policy Insight No. 79, February.

Gechert, S.; Rietzler, K.; Tober, S. (2015): The European Commission's New NAIRU: Does it Deliver? Applied Economics Letters, forthcoming.

German Council of Economic Experts (2011): Stable Architecture for Europe - Need for Action in Germany. Annual Report 2011/12, Wiesbaden.

\footnotetext{
${ }^{20}$ This important role was recently also emphasized by ECB President Draghi (2014): „Turning to fiscal policy, since 2010 the euro area has suffered from fiscal policy being less available and effective, especially compared with other large advanced economies. This is not so much a consequence of high initial debt ratios - public debt is in aggregate not higher in the euro area than in the US or Japan. It reflects the fact that the central bank in those countries could act and has acted as a backstop for government funding. This is an important reason why markets spared their fiscal authorities the loss of confidence that constrained many euro area governments' market access. This has in turn allowed fiscal consolidation in the US and Japan to be more backloaded."

${ }^{21}$ In a monetary union, this important role of the central bank presupposes that the sovereign bonds of member states are safe assets and that institutional regulations are in place that promote fiscal sustainability and prevent sovereign defaults. During the past years rather than fortifying the trust in euro-area government debt as reliable stores of value, governments have undermined it by, for example, explicitly not excluding the possibility of default and including collective action clauses in euro-area government bonds (Tober 2014a).
} 
Horn, G. et al. (2015): Wirtschaftspolitische Herausforderungen 2015 - Wirtschaftspolitik unter Zwängen. IMK Report 102, Duesseldorf.

iAGS (2014): iAGS 2015 - independent Annual Growth Survey Third Report. OFCE/IMK/ECLM, Brussels.

Logeay, C. and Tober, S. (2006): Hysteresis and the NAIRU in the Euro Area, Scottish Journal of Political Economy 53(4), 409-429.

Parello, C. P.; Visco, V. (2012): The European Redemption Fund: A Comparison of two proposals. MPRA Paper No. 42874, Munich.

Pâris, P.; Wyplosz, C. (2014): The PADRE plan: Politically Acceptable Debt Restructuring in the Eurozone. VOX CEPR's Policy Portal, 28 January 2014.

Pâris, P; Wyplosz, C. (2014b): PADRE: Politically Acceptable Debt Restructuring in the Eurozone. Geneva Special Report on the World Economy 3, ICMB and CEPR.

Pâris, P.; Wyplosz, C. (2013): To end the Eurozone crisis, bury the debt forever. VOXEU, August.

Philippon, T. and Hellwig, C. (2011): Eurobills, not Eurobonds. VOXEU, December.

Tober, S. (2014a): Risky or Safe: Government Bonds in the Euro Crisis. In: Restoring Shared Prosperity - A Policy Agenda from Leading Keynesian Economists, edited by G. Horn and T. Palley. January 2014.

Tober, S. (2014b): Debt Redemption Fund: Conditio Sine Qua Non? Government Bonds in the Euro Area Crisis. IMK Working Paper Nr. 131/2014.

Tumpel-Gugerell et al. (2014): Expert Group on Debt Redemption and Eurobills. Final Report. EU Commission, Brussels, 31 March 2014.

Varoufakis, Y; Holland, S. and Galbraith, J.K. (2013): A Modest Proposal for Resolving the Eurozone Crisis - Version 4.0 (July 2013)

Vergote, O. and Studener, W. (2010): Main Drivers of the ECB Financial accounts and the ECB Financial Strength Over the First 11 Years. Occasional Paper Series No. 111, May 2010.

Villalón, C. (2015): Opinion of the Advocate General, Case C-62/14. European Court of Justice, 14 January 2015.

Watt, A. (2015): Quantitative easing with bite: a proposal for conditional overt monetary financing of public investment. IMK Working Paper, Nr. 148.

Whelan, Karl (2014): Can you really make losses printing money? Blog 3 October 2014.

Wren-Lewis, S. (2013): What is the attraction of helicopter money? Mainly Macro, 8 February 2013. 
Publisher: Hans-Böckler-Stiftung, Hans-Böckler-Str. 39, 40476 Düsseldorf, Germany Phone: +49-211-7778-331, IMK@boeckler.de, http://www.imk-boeckler.de

IMK Working Paper is an online publication series available at: http://www.boeckler.de/imk 5016.htm

ISSN: $1861-2199$

The views expressed in this paper do not necessarily reflect those of the IMK or the Hans-Böckler-Foundation.

All rights reserved. Reproduction for educational and non-commercial purposes is permitted provided that the source is acknowledged. 